\title{
Dialogue Document Without a Dialogue: Current Debates on World War II in Croatia
}

Abstract: Koren Snježana, Dialogue Document Without a Dialogue: Current Debates on World War II in Croatia. "Poznańskie Studia Slawistyczne" 16. Poznań 2019. Publishing House of the Poznan Society for the Advancement of the Arts and Sciences, Adam Mickiewicz University, pp. 143-157. ISSN 2084-3011.

The article deals with the recent controversies over the interpretations of World War II. The dominant narrative of World War II, which was created after 1945 to ensure the basis of legitimacy for the Yugoslav Communist regime, was revised at the beginning of the 1990s. One of the consequences of this revision has been the upsurge of historical revisionism regarding the fascist Ustashe movement. After years of bitter debates that had divided and polarized the Croatian society, the government appointed in 2017 a special council to deal with the World War II past and make the recommendations on the public usage of the symbols and insignia of the $20^{\text {th }}$ century "undemocratic regimes". The final product of its work was the so-called Dialogue Document whose provisions and impact are dealt with in the second part of the text.

Keywords: World War II; Dialogue Document; reconciliation; the Ustashe insignia; Jasenovac

\section{World War II and the politics of history in Croatia since 1990}

In March 2017, the Croatian government made a decision to establish the Council for Dealing with the Consequences of Undemocratic Regimes that was made up of representatives of Croatia's top scientific, cultural and memorial institutions. The Council was charged with the task to draft comprehensive recommendations aimed at dealing with the legacy of the $20^{\text {th }}$ century "undemocratic regimes". The term "undemocratic regimes" in this context referred to World War II movements, organizations and regimes, 
as well as the socialist Yugoslavia era. ${ }^{1}$ The World War II topics have been in the center of bitter debates ever since Croatia gained its independence at the beginning of the 1990s. The roots of these political debates and ideological conflicts need to be traced not only in World War II events, but also in post-1945 and post-1990 interpretations of these events.

There was a massive conflict on the territory of Yugoslavia between 1941 and 1945. As a consequence of military operations and air-raids, a brutal civil war, mass executions and retaliations, the Holocaust and the Porajmos, the human cost of the war was enormous. It is estimated to have been around one million out of approximately 16 million inhabitants in Yugoslavia before the war; civilian victims made up more than half of that number. During the war, Croats were politically and ideologically divided between the Partisan movement, led by the Communist Party of Yugoslavia (hereafter: the KPJ), and the Independent State of Croatia (hereafter: the NDH) run by the Ustashe. The main goals of the Partisans and their Communist leadership were to fight the Axis occupying forces and their collaborators and to restore Yugoslavia, a former monarchy, as a federal republic with a Soviet-style government. The KPJ was founded in 1919, but it was banned soon afterwards and remained an illegal underground group for the rest of the interwar period; at the time, it was firmly linked to the USSR and the Comintern. Its leadership (with Josip Broz Tito as its secretary general since 1937) launched the Partisan resistance movement soon after the occupation of Yugoslavia in April 1941. At the same time, the Ustashe were appointed to rule the NDH, a fascist puppet state established by the Axis. The Ustashe movement was founded in Italy at the beginning of the 1930s, emphasizing as its aim the formation of an independent Croatia. The ideology of this movement was a blend of fascism and Croatian nationalism. During World War II, the Ustashe regime committed genocide against Serbs, Jews and Roma and murdered numerous antifascists. Partisans carried out the main fighting against the Axis and its collaborators and got support from the major Allied powers - consequently, after the war Yugoslavia was restored as a federal republic and a communist state. During and after the final stages of the war, Partisan

${ }^{1}$ The decision of the Government of Republic of Croatia on establishing the Council for Dealing with the Consequences of Undemocratic Regimes, March 2, 2017. 
units and the Yugoslav authorities carried out reprisals, including forced marches and mass executions of tens of thousands captured collaborators, deportations of ethnic Germans, atrocities against Italians, etc (Tomasevich, 2001, 718-750). In post-war Yugoslavia, the "National Liberation Struggle" (this is how the 1941-1945 war used to be called in Yugoslavia; hereafter: the NOB) was a topic of particular significance. The story of how the KPJ organized and led a successful resistance movement of all Yugoslav nations fighting against fascism was meant to ensure the basis of legitimacy for the Yugoslav Communist regime. The atrocities committed by Partisan forces during and immediately after World War II were never mentioned and never became part of the official narrative (e.g., in history textbooks; Koren, 2012, passim).

In the period of political changes that occurred in Croatia during and after the collapse of Yugoslavia, it was precisely this narrative of World War II that came under scrutiny, which was very much determined by the contemporary political needs. Since 1990, the most influential political party in Croatia has been the Croatian Democratic Union (hereafter: the HDZ). The HDZ was founded in 1989 and it has been in power for most of the period since 1990 (1990-2000, 2003-2011, and since the beginning of 2016). It is a conservative right-wing party; its political attitudes vary from center-right to radical-right. The politics of history of the HDZ has strongly been colored by the ideology of ethnic nationalism. In early 1990s, its political leadership pushed for the creation of an independent and ethnically homogeneous Croatian state. In order to achieve this goal, they promoted the idea of "national reconciliation" among the Croats, i.e. among the former World War II adversaries (the Partisans and the Ustashe) and their descendants. But, this concept of reconciliation was also very much driven by the needs of the HDZ leadership to reconcile conflicting narratives within the party. Some of the founders of the HDZ were former communists, former members of the Yugoslav army, police, and secret services; at the same time, they needed the support from émigré circles who were very much influenced by those who fled Croatia at the very end of World War II either because they were strongly affiliated with the NDH or because they were opponents of the Yugoslav Communist regime (Koren, 2015, 11-17). Another important element of the HDZ politics of history was the claim that Croats managed to preserve an uninterrupted continuity 
of their state since the Early Middle Ages, struggling against forces that tried to prevent them to make an independent state (the "thousand-year national identity and state continuity of the Croatian nation" and the "historical right of the Croatian nation to full state sovereignty", as it is said in the introduction to the Croatian Constitution adopted in $1990^{2}$ ).

As a consequence of this politics of history, the monolithic, uncritical and rather mythologized narrative from the Communist period was replaced with another, equally monolithic, uncritical and mythologized. Its purpose was not to encourage a pluralist view of the Croatian contemporary history, but to replace one official history ("one truth") with another. In this new narrative of the $20^{\text {th }}$ century history, both Yugoslav states were presented as entities that were created only to secure Serbian domination and therefore as essentially anti-Croat. The legacy of the Partisan movement became problematic because it involved not only fighting against fascism, but also the reconstruction of Yugoslavia after the war. Another consequence of this politics of history has been the upsurge of historical revisionism regarding the Ustashe who have been, especially among radical-right groups, rehabilitated as fighters for an independent Croatia. Public display of the Ustashe insignia, and using of the Ustashe salute "For Home-Ready", although prohibited by the law, ${ }^{3}$ has increasingly been tolerated. Thousands of monuments erected to memorialize the Partisan struggle or the KPJ history were destroyed or damaged during the 1990s; names that recalled a partisan fight during World War II or the achievements of socialism have been removed from public spaces. However, these practices remain the source of constant conflict between those who want these street names or monuments to be removed and those who oppose such actions (Rihtman-Auguštin, 2000; Stanić, Šakaja, Slavuj, 2009; Pavlaković, 2011). For example, attempts to change the name of the Square of Victims of Fascism in Zagreb led even to physical clashes in the 1990s; Zagreb city

${ }^{2}$ The Croatian Constitution (2010). Part I. Historical Foundations.

${ }^{3}$ The existing Penal Code (Article 325) sanctions denial of genocide, war crimes, crimes against humanity and crimes of aggression, provided that such denial is aimed at fostering national, ethnic, racial, religious etc. hatred or violence. It also sanctions the activities that call for violence or hatred against a group of people or an individual member of the group because of their race, religion, national or ethnic affiliation, origin, color, sex, sexual orientation, gender identity or disability. 
assembly voted to strip the Tito's name from one of the city's main squares in 2017, a decision that has remained controversial to date.

In the search of a "thousand-year continuity of the Croatian state", even the establishment of the NDH was reinterpreted as a positive historical fact at the beginning of the 1990s. In the official discourse, Ustashe atrocities were formally condemned, but in reality marginalized and suppressed. ${ }^{4}$ The story of the mass killings of war prisoners committed by Partisans at the end of the war that was suppressed in the history books of socialist Yugoslavia was now given a prominent place. The Croatian Parliament became a sponsor of annual commemorations near the town of Bleiburg on the Austrian-Slovenian border, which memorialize events at the very end of the war when Partisan forces committed mass liquidations of captured war adversaries, mostly soldiers of the NDH. The Bleiburg commemorations have been controversial because they were established in the 1950 s by Croatian émigré circles and regularly served not only to pay homage to the victims, but also as a memorial celebration of the NDH (Pavlaković, Pauković, Brentin, 2018; Tokić, 2018). On the other hand, there have also been periods since 1990 when this narrative was, more or less intensively, called into question, especially when the left or left-liberal political parties were in power (for example, in 2000-2003 or 2011-2015, during the coalition governments led by Social Democrats, the largest party of the Croatian center-left which evolved from the former League of Communists of Croatia).

\section{Recent debates and Dialogue Document}

The intensity of these debates was temporarily diminished during the EU accession process when the major political parties were oriented towards the future and dealing with the past did not play such a prominent role in their politics (although the debates about the 1991-1995 war and

${ }^{4}$ In the official history textbook published in 1992 there were seven pages in the lesson about the NDH. There was a lot of material dedicated to the territorial organization, political institutions and the armed forces of the NDH, as well as culture in the NDH, but only half of one sentence was dedicated to the atrocities committed by the Ustashe regime against Serbs, Jews and Roma (Perić, 1992, 103-105). 
the legacy of the 1990s erupted at the same time). But after Croatia joined the EU in 2013, a trend of nationalism began to reappear, which coincided with the escalation of the economic crisis. This renewed trend of nationalism was evident in the last presidential and general election campaign (2014 and 2015). Especially the then oppositional HDZ, as well as some other right-wing political parties, returned to the nationalist rhetoric of the 1990s and used historical themes as part of their campaign strategy. (cf. Jović, 2015) They demanded lustration of the former members of the Communist Party (even though they could be found in both major political parties), removal of the Josip Broz Tito's name from all public spaces, rewriting school history curricula and textbooks, and instilling patriotism through culture and education. They also claimed that the communist crimes were not researched properly and for that reason the sentiments about the period of socialist Yugoslavia still exist in the Croatian society. ${ }^{5}$ These groups have formally adopted the politics of memory of the European Parliament resolution on European conscience and totalitarianism (2009) and claim that they are against "all totalitarianisms". They strongly condemn "the Communist crimes in Croatia", but as a rule are reluctant to clearly address and condemn the crimes of the Ustashe regime and the legacy of the NDH. ${ }^{6}$ These groups tend to reject any positive memory of the Partisans as a resistance and antifascist movement and place it only in the context of war atrocities and the creation of Communist Yugoslavia. They also claim that the reconciliation in the 1990s was misused by those who "never got over the breakup of Yugoslavia and never wanted an independent Croatia" and who allegedly want to restore Yugoslavia. ${ }^{7}$ In reality, there is no political party or any significant political actor in Croatia who would advocate such ideas and this backlash against imaginary Yugoslavs is used only as a means to fight political battles (cf. Cipek, 2017). In the

${ }^{5}$ E.g. statements of Tomislav Karamarko, the leader of the HDZ at the time (Koren, 2015, 11-16).

${ }^{6}$ E.g. the speech by President of the Croatian Parliament Željko Reiner on commemorating the European Day of Remembrance of Victims of All Totalitarian and Authoritarian Regimes, August 23, 2016. Retrieved from: http://www.sabor.hr/hr/zastupnici/predsjednik/ govori/govor-predsjednika-hrvatskoga-sabora-zeljka-reinera-na-obiljezavanju

${ }^{7}$ E.g. "Moj antikomunistički manifest," an interview with Tomislav Karamarko in Globus, no. 1276, May 22, 2015. 
long run, however, all these political strategies and tactics in the last quarter of the century have had a negative effect because they did not resolve any of the open questions about the past, either those about crimes committed during World War II or human rights violations during the Yugoslav communist regime. Because these strategies are mostly used as a means to fight short-term political battles, they constantly re-open another circle of recriminations and fruitless debates in an already polarized society (cf. Blanuša, 2017).

After the 2015 general election, the conservative coalition of different parties and groups (ranging from moderate, center-right groups to radical right groups which based their program on rigid nationalism and socially conservative views), led by the HDZ, formed the government in January 2016. The conservative coalition government continued to deepen ideological rifts in the society with its radical rhetoric, threaten freedom of expression, and put political pressure on state-funded public media. After only four and half months, however, it lost support in the Parliament. Snap elections ensued, and more moderate center-right government (still led by the HDZ) took office in October 2017. The new party leadership seeks to move away from the ideological conflicts of the past. But there are other, more radical factions in the HDZ that continue to use history as a means to revive contemporary political debates and divisions. Furthermore, in the last couple of years, there has been a growing number of other groups within society who try to rehabilitate the NDH and downplay or even negate crimes and genocide committed by the Ustashe regime. There has also been a number of other similar incidents associated with the glorification of the NDH, such as chanting the Ustashe salute at sports events and concerts, ${ }^{8}$ the celebration of April 10, the date when the NDH was established (Pavlaković, 2008), the displaying of Ustashe symbols,

\footnotetext{
${ }^{8}$ In a 2013, a player of a national football team, Joe Simunic, led the public in the stadium to chant the Ustashe slogan "For Home-Ready" after the victory against Island in qualifications for the World Championship. He was sentenced by FIFA and banned from playing in 10 following games for the national team, which prevented him from participating in the World Championship in Brasil. Another well-known case is the one of a popular singer Marko Perković Thompson, who regularly starts his concerts with a song that begins with the chant For Home-Ready (the song was made in 1991). This is often overlooked in Croatia, but his concerts were banned in several European countries (Austria, Switzerland, Netherlands, Slovenia, Germany, Bosnia and Herzegovina).
} 
etc. In November 2018, The Office of Ombudsman warned in an analysis that attempts of World War II historical revisionism and downplaying the Ustashe crimes undermine the fundamental values of the Constitution. ${ }^{9}$

The most poignant part of this historical negationism has been battling over the number of victims of the largest death and concentration camp in the NDH, Jasenovac that was established and run by the Ustashe. Tens of thousands of Serbs, Jews, Roma, anti-fascist or dissident Croats and other inmates were murdered there between 1941 and 1945. Recent estimates indicate that the Ustashe regime murdered between 90,000 and 100,000 people in Jasenovac. ${ }^{10}$ In recent years, however, there are a number of groups who openly negate the character of Jasenovac as a death camp and try to minimize the number of victims (cf. Kasapović, 2018). One of these groups, the Society for Research of the Threefold Jasenovac Camp, denies that there was a death camp in Jasenovac in the period of 1941-1945 (for them, it was only a work camp for the opponents of the NDH) and claims, without any proofs, that the Yugoslav Communists established two concentration camps on the site of the former Ustashe camp in the second half of the 1940s, one immediately after World War II and another during the Tito-Stalin split. The Society was granted around 6600 Euros for its research into archival material by the War Veterans' Ministry in 2017. ${ }^{11}$ The book on Jasenovac (titled Work Camp Jasenovac) published by the Society was promoted at the state-funded public television. ${ }^{12}$ Furthermore, the public institution Jasenovac Memorial Site published a report stating

9 "Relativisation of the Ustasha crimes violates the fundamental values of the Constitution, with a lack of reaction opening room to hatred" (2018, November 20). Retrieved from: http://ombudsman.hr/en/all-news/discrimination/discrimination-article/1497-relativisationof-the-ustasha-crimes-violates-the-fundamental-values-of-the-constitution-with-a-lack-ofreaction-opening-room-to-hatred .

${ }^{10}$ Since World War II, there has been much debate and controversy regarding the character and the number of victims killed at the Jasenovac camp. For more details on the history of Jasenovac and on the debates about Jasenovac v. Goldstein, Goldstein, 2011; Goldstein, $2016 ; 2018$.

${ }^{11}$ V.: "Društvo započelo provedbu projekta s podrškom Ministarstva hrvatskih branitelja" (2018, January 2). Retrieved from: https://drustvojasenovac.wordpress.com/2018/01/03/ drustvo-zapocelo-provedbu-projekta-s-podrskom-ministarstva-hrvatskih-branitelja/.

${ }^{12}$ V.: "Priopćenje Javne ustanove spomen-područja Jasenovac povodom gostovanja Igora Vukića u emisiji "Dobar dan, Hrvatska" Hrvatske radiotelevizije" (2018, June 4). Retrieved from: http://www.historiografija.hr/?p=10156. 
that only 9 school groups visited the site of the former concentration camp in 2017; a report for 2018 shows modest increase in number of organized visits of students (15 groups). ${ }^{13}$

In this political context, the Croatian government came to a decision to establish the Council for Coming into Terms with the Consequences of Undemocratic Regimes (hereafter: the Council). The government first mentioned setting up the Council during a heated controversy over a commemorative plaque with Ustashe slogan "For Home-Ready". The plaque was installed in November 2016 on the kindergarten's building in a small town of Jasenovac, near the Jasenovac Memorial Site. It was commissioned and installed by some veteran members of the paramilitary unit from the 1991-1995 war, the Croatian Defense Forces (hereafter: the HOS). This unit bore the same name as the armed forces of the NDH in 1944-1945 and used the Ustashe insignia during the war. It still uses the salute "For Home-Ready" as part of its officially approved coat of arms. Many called for the immediate removal of the plaque, and when the government failed to do that, Jewish and Serbian organizations boycotted annual Jasenovac commemoration (it was the second boycott in a row). But, any such action was strongly opposed by some associations of war veterans from the 1991-1995 war. The "Homeland War" - this is how the 1991-1995 war is officially called in Croatia - has been in recent years increasingly portrayed as a decisive event in Croatian history, the "victory of the Croatian people and Croatian defenders in the just, legitimate, defensive and liberating Homeland War". ${ }^{14}$ It often leads to an uncritical glorification of the war, and any attempt of criticism is qualified as "belittling of the values of the Homeland War and its heroes". (Jović, 2017, passim) Although these groups acknowledge that the salute "For Home-Ready" was used by the Ustashe, they justify its use by claiming that it is actually an old Croatian salute (in fact, there is a wide consensus among historians that it originated from the Ustashe movement). For them, the salute was somehow "redeemed" because it was also used by the Croatian soldiers during the 1991-1995 war, although it was used exactly to

${ }^{13}$ For the reports v.: http://www.jusp-jasenovac.hr/Default.aspx?sid=8815 (the report for 2017) and http://www.jusp-jasenovac.hr/Default.aspx?sid=5027 (the report for 2018).

${ }^{14}$ The Croatian Constitution, Part I. Historical Foundations. The term Croatian defenders is officially used in Croatia to designate soldiers in the Croatian Army during the 1991-1995 war. 
evoke the memory of the Ustashe and the NDH in the fight against the Serbs. The following two statements made in a political talk-show on a public television illustrate these polarized views: $:^{15}$

Any attack [...] on the HOS, on its contribution to the Homeland War, on its wartime insignia, on its war record, is also an attack on the Homeland war, and thereby an attack on the Croatian state. (Anto Đapić, a politician and an active member of the HOS during the 1991-1995 war).

If you celebrate April 10, if you name your unit after the officer of the Ustashe army in World War II, if you use a salute that was used at the time, if you have the same color of uniform as the Ustashe had, and if you, in your speech on April 10, 2016 in the city of Split, say that the NDH was the only Croatian state when a dream came true for a short period of time, then you cannot say that you have nothing to do with World War II. (Arsen Bauk, a politician from the SDP, in response to Đapić's claim that the HOS has nothing to do with World War II).

Because of these contemporary echoes of the World War II allegiances and divisions, the Council's task was not only to deal with the war past. It also included the making of recommendations regarding the legal regulation of the use of the insignia and symbols of "undemocratic regimes", as well as proposals for the scientific research, the politics of remembrance (whether the figures from these regimes should have public spaces named after them), and "ways of educating children and adolescents in connection with violations of human rights and fundamental freedoms during the government of undemocratic regimes". ${ }^{16}$ Although it was not explicitly mentioned among its tasks, the making of the recommendations of the legal regulation for the use of the symbols of non-democratic regimes obviously meant dealing with the 1991-1995 war as well. That was another sensitive topic that needed to be addressed by the Council.

The Council was given one year to fulfill these tasks. At the beginning of its work, the president of the council said to the media that "the Council's basic objective is to replace a practice of intolerance with a constructive dialogue". It will also seek "to ease the way towards reconciliation

${ }^{15}$ These statements were made in the political talk-show Otvoreno on the Croatian Television (2018, November 29). Retrieved from: https://vijesti.hrt.hr/475247/otvoreno-ooptuzama-za-toleriranje-povijesnog-revizionizma.

${ }^{16}$ The decision of the Government of Republic of Croatia on establishing the Council for Dealing with the Consequences of Undemocratic Regimes, March 2, 2017. 
in the society, tackle uncritical positions on the both regimes, as well as preventing young people from being subjected to politically motivated interpretations of history. He expressed optimism that the recommendations „will serve as a landmark for the future and in the long run, will contribute to calming passion and overcoming divisions" (quoted in Milekic, 2017b). It was clear, however, that the Council was given a complex task, and from the outset many were skeptical about the possibilities of achieving these ambitious goals or even reaching a consensus among the Council's members because of their differing views. Others warned that the real purpose of establishing the Council was far more prosaic: it was founded to buy the government some time before it makes a political decision about the removal of the plaque from Jasenovac (e.g. Milekic, 2017a).

In early March 2018, after months of going back-and-forth, the Council announced that it produced a document which was supposed to serve as a basis for the drafting of legal regulations. It was named Dialogue Document. The document was a compromise, albeit a difficult one: at its meeting on 28 February 2018 the Council adopted the conclusion that the Document was acceptable to some members, but only partially acceptable to others. The Council decided not to vote on its final version, but those members who had differing views should later deliver their statements as dissenting opinions. Eight out of the total of 17 Council members used that opportunity!

The first part of the document ${ }^{17}$ describes a historical background of the Croatian experience with "undemocratic regimes" in the $20^{\text {th }}$ century and defines the key concepts, fascism and communism. The definition of communism focuses on how it "seeks to achieve comprehensive authority over all segments of society" (the existence of only one allowed party associated with an administrative system and a repressive apparatus, mass persecution and victims among "class enemies" and other "hostile elements" etc.). In much shorter definition, fascism is more or less reduced to nationalism and nationalist expansion, while all other aspects that are crucial to understanding this phenomenon are ignored (Dialogue Document, 1). The document lists particular communist crimes during and after World War II in Yugoslavia, but it fails to do so regarding the "fascist"

${ }^{17}$ For the detailed analysis of Dialogue Document v.: Cvijanović, 2018, 122-141. 
crimes - they are recognized only in general terms. Thus, using fascism as an umbrella term proves to be particularly problematic in the Croatian context because it enables to avoid mentioning the concrete crimes committed by the Ustashe and the NDH regime.

In the second part of the document there are the recommendations for the legal regulation for the use of the insignia and symbols. There are no recommendations for the education on undemocratic regimes, but it should not be surprising because there were no education experts among the members of the Council. It is recommended to the legislators that only "prima facie disputed insignia of hate could be subject to a special regime of blanket prohibitions“. Following insignia are explicitly mentioned: „the fascist Roman salute, the so-called Hitler salute accompanied by the words Sieg heil, the Nazi swastika, the Nazi "SS" emblem, the Chetnik cockade, the Ustasha "U", the Ustasha salute "Za dom i poglavnika (For the homeland and its leader)" and "Za dom spremni (For the homeland ready)". One exception, however, is tolerated: the use of the salute "For Home-Ready" should be allowed for commemorative purposes only, in places or cemeteries where members of the HOS died or were buried (Dialog Document, 24-30).

It is also recommended that "it would not be appropriate for disputed insignia that (also) have other, positive meanings [...] and are not unambiguously recognized as insignia of hate [...] to be subject to a blanket prohibition". The five-pointed red star and the wartime slogan of the Partisan movement Death to fascism, freedom to the people were declared "indisputable" in all those circumstances when they are used to mark the antifascist struggle. But, because of their negative connotations regarding human rights violations and mass crimes during the Yugoslav communist rule, as well as usage of the red star by the Yugoslav Army during the 1991-1995 war, it was left to the legislature to decide how to deal with situations in which they are used to promote hatred or violence (Dialog Document, 24-30). Precisely this conclusion was the point of controversy which led eight members of the Council to deliver separate opinions. In one of these opinions it is said that it is unacceptable for the signatories that those symbols and insignia that are identified "with the ideas of communist totalitarianism" are not included among unambiguously controversial symbols. ${ }^{18}$ In another dissenting opin-

\footnotetext{
${ }^{18}$ Dissenting opinion on the Dialogue Document by M. Ančić et al.
} 
ion, it is stated that by accepting this document, the Council will give a new impetus to the "old leftist argument that communism, with all the totalitarian deficiencies, is still more acceptable than fascism." 19

As it could be expected, such recommendations did not satisfy anybody: some were dissatisfied because the Council did not recommend that the communist symbols such as the red star should be forbidden by the law, and others by the fact that the usage of Ustashe salute was permitted in certain circumstances. For a couple of days there was a heated debate in the media, and then the Dialogue document slid into oblivion. No law on historical memory that was at one point announced by the government as an extension of these recommendations, has been produced. ${ }^{20}$ The commemorative plaque with the slogan "For Home-Ready", which triggered the government's decision about setting up the Council, was removed from Jasenovac already in September 2017 and transferred to another location, 10 kilometers away from its original position. In a way, it seems as if the Council's contradictory recommendations that the Ustashe salute and symbols can be used in special circumstances even though they violate the law, served only to belatedly sanction this government's action. Fruitless efforts of the Council for Dealing with the Consequences of Undemocratic Regimes are in a way an epitome of Croatia's troubled dealing with its $20^{\text {th }}$ century history. The divided memory of World War II, and the way it is dealt with in the political arena, will likely continue to create ideological rifts, entrench the polarized groups in the society and, most probably, undermine coming into terms with the $20^{\text {th }}$ century past. Obviously, these debates are not only about the past, but they point at the values that are important to the contemporary Croatian society. This is one of the key reasons why they have been debated so bitterly.

${ }^{19}$ Dissenting opinion on the Dialogue Document by Ž. Tanjić.

${ }^{20}$ Minister of Justice mentioned in political talk-show Otvoreno on the Croatian Television in November 2018 that the existing framework set by the article 325 of the Penal Law is good, and that the Ministry of Justice it only reconsidering whether "some things should be defined more precisely". Retrieved from https://vijesti.hrt.hr/475247/otvoreno-o-optuzamaza-toleriranje-povijesnog-revizionizma. 


\section{References}

Blanuša, N. (2017). Trauma and taboo: forbidden political questions in Croatia. "Croatian Political Science Review" vol. 54, no. 1-2, pp. 170-196.

Cipek, T. (2017). The spectre of communism is haunting Croatia. The Croatian Right's Image of the Enemy. "Croatian Political Science Review" vol. 54, no. 1-2, pp. $150-169$.

Cvijanović, H. (2018). On memory politics and memory wars: a critical analyiss of the Croatian Dialogue Document. "Croatian Political Science Review" vol. 55, no. 4, pp. $122-141$.

Jović, D. (2015). First 'return to Europe', then to the 1990s. „Balkans in Europe Policy Blog “, University of Graz: Centre for Southeast European Studies. https://biepag. eu/first-return-to-europe-then-to-the-1990s/?highlight=Jovi\%C4\%87.

Jović, D. (2017). Rat i mit. Politika identiteta u suvremenoj Hrvatskoj. Zagreb, Fraktura.

Goldstein, I. (2018). Jasenovac. Zagreb: Fraktura.

Goldstein, S. (2016). Jasenovac: tragika, mitomanija, istina. Zagreb: Fraktura.

Goldstein, S., Goldstein, I. (2011). Jasenovac i Bleiburg nisu isto. Zagreb: Novi Liber.

Kasapović, M. (2018). Genocid u NDH: Umanjivanje, banaliziranje i porianje zločina. "Politička misao" vol. 55, no. 1, pp. 7-33.

Koren, S. (2012). Politika povijesti u Jugoslaviji (1945-1960). Komunistička partija Jugoslavije, nastava povijesti, historiografija. Zagreb: Srednja Europa.

Koren, S. (2015). Twentieth-century wars in history teaching and public memory of present-day Croatia. "Studi sulla formazione" no. 2, pp. 11-32.

Milekić, S. (2017a). Croatia's undemocratic past creates present-day problems. "BalkanInsight". http://www.balkaninsight.com/en/article/croatia-s-undemocratic-pastcreates-present-day-problems-03-06-2017.

Milekić, S. (2017b). Croatia's Undemocratic Regimes Council's mission still unclear. "BalkanInsight". http://www.balkaninsight.com/en/article/croatian-council-for-undemocratic-regimes-meets-06-30-2017-1.

Pavlaković, V. (2008). Opet „Za dom spremni“. Desetotravanjske komemoracije u Hrvatskoj nakon 1990. godine. In: Kultura sjećanja: 1941. Povijesni lomovi i svladavanje prošlosti. Ed. S. Bosto, T. Cipek, O. Milosavljević. Zagreb: Disput, pp. 113-129.

Pavlaković, V. (2011). Sukob, komemoracije i promjene značenja: Meštrovićev paviljon kao prijeporno mjesto sjećanja. In: Kultura sjećanja: 1991. Povijesni lomovi i svladavanje prošlosti. Ed. T. Cipek. Zagreb: Disput, pp. 215-238.

Pavlaković, V., Pauković D., Brentin D. (2018). The Controversial commemoration: transnational approaches to remembering Bleiburg. "Croatian Political Science Review" vol. 55, no. 2, pp. 7-32.

Perić, I. (1992.). Povijest za VIII. razred osnovne škole, I. izdanje. Zagreb: Školska knjiga.

Rihtman-Auguštin, D. (2000). Ulice moga grada. Beograd: Biblioteka XX vek. 
Stanić, J., Šakaja, L., Slavuj, L. (2009). Preimenovanje zagrebačkih ulica i trgova. "Migracije i etničke teme" no. 25, 1-2, pp. 89-124.

Tokić, M.N. (2018). Avengers of Bleiburg. Émigré politics, discourses of victimhood and radical separatism during the Cold War. "Croatian Political Science Review" vol. 55, no. 2, pp. 71-88.

Tomasevich, J. (2001). War and revolution in Yugoslavia, 1941-1945: occupation and collaboration. Stanford: Stanford University Press.

\section{Documents}

Dialogue Document: Postulates and Recommendations on Specific Normative Regulation of Symbols, Emblems and other Insignia of Totalitarian Regimes and Movements, the Council for Dealing with the Consequences of Undemocratic Regimes. (2018). https://vlada.gov.hr/UserDocsImages/Vijesti/2018/05\%20svibanj/5\%20 svibnja/DOKUMENT\%20DIJALOGA\%20ENG.pdf.

Dissenting opinion on the Dialogue Document by Željko Tanjić. (2018). https://vlada.gov.hr/UserDocsImages//Vijesti/2018/02\%20veljača/28\%20veljače//Mišljenje\%20prof.\%20dr.\%20sc.\%20Željka\%20Tanjića.pdf.

Dissenting opinion on the Dialogue Document by Vanja Ivan Savić. (2018). https:// vlada.gov.hr/UserDocsImages//Vijesti/2018/02\%20veljača/28\%20veljače//Dopunsko\%20mišljenje\%20doc.\%20dr.\%20sc.\%20Vanja-Ivan\%20Savić.pdf.

Dissenting opinion on the Dialogue Document by Aleksandar Jakir. (2018). https:// vlada.gov.hr/UserDocsImages//Vijesti/2018/02\%20veljača/28\%20veljače//Mišljenje\%20prof.\%20dr.\%20sc.\%20Aleksandar\%20Jakir.pdf.

Dissenting opinion on the Dialogue Document by Mladen Ančić, Nataša Jovičić, Ivo Lučin, Ante Nazor, and Nevio Šetić. (2018). https://vlada.gov.hr/UserDocsImages// Vijesti/2018/02\%20veljača/28\%20veljače//Mišljenja\%20prof.\%20dr.\%20sc.\%20 Mladena\%20Ančića, \%20Nataše\%20Jovičić,\%20dr.\%20sc.\%20Ive\%20Lučića,\%20doc.\%20dr.\%20sc.\%20Ante\%20Nazora\%20i\%20prof.\%20dr.\%20sc.\%20 Nevija\%20Šetića.pdf.

European Parliament resolution of 2 April 2009 on European conscience and totalitarianism. http://www.europarl.europa.eu/sides/getDoc.do?pubRef=-//EP//TE$\mathrm{XT}+\mathrm{TA}+\mathrm{P} 6-\mathrm{TA}-2009-0213+0+\mathrm{DOC}+\mathrm{XML}+\mathrm{V} 0 / / \mathrm{EN}$.

The Croatian Constitution. (2010). "Narodne novine: službeni list RH" no. 85/2010. https://narodne-novine.nn.hr/clanci/sluzbeni/2010_07_85_2422.html.

The decision on establishing the Council for Dealing with the Consequences of Undemocratic Regimes. (2017). https://vlada.gov.hr/UserDocsImages/Vijesti/2018/02\%20 veljača/28\%20veljače/Odluka\%20o\%20osnivanju $\% 20 \mathrm{i} \% 20$ članovi.pdf.

The Penal Code. (2011). "Narodne novine: službeni list RH" 125/11, 144/12. https:// narodne-novine.nn.hr/clanci/sluzbeni/2011_11_125_2498.html. 